https://doi.org/10.5817/0S2021-3-8

\title{
Paríž v slovenskom a českom umení
}

VAŠŠ, M.: Zmenení Parížom, slovenskí umelci a Paríž v 2o. storočí. Bratislava: Marenčin PT 2020, 243 s. ISBN 978-80-569-0443-5.

Historik Martin Vašš (1983) svojím výskumom zotrváva na užitočnom a pre svoju náročnost’ aj obchádzanom pomedzí viacerých súčastí spoločenských vied. Podla informácie na prebale posledného knižného titulu Zmenení Parížom z roku 2020 „sa venuje slovenským politickým, kultúrnym a sociálnym dejinám 20. storočia..... Literárna história si jeho záujem o kultúrne a literárne dejiny pripomína prostredníctvom jeho prác Bratislavská umelecká bohéma v rokoch 1920-1945 (2016), Zlatá bohéma (2018) a Medzi snom a skutočnostou (2018).

Predpoklad, že pri štúdiu (moderných) slovenských politických dejín mu dostupný a získaný osobný aj odborný materiál poskytli rozprávačskú aj užitočnú výzvu na „príbehové“ práce, ktorými by pre nevyhraneného čitatela ilustroval prostredníctvom personálnych epizód činy aj udalosti z emancipácie slovenskej a okrajovo aj českej, mad’arskej či nemeckej kultúry na území Slovenska v minulom storočí. Príbeh budúceho slovenského vel'komesta, v ňom nové spoločenské a sociálne prostredie pre mnohých umelcov z regiónov krajiny, zvýraznenie nemálo pre jeho tvorbu zaujímavých lokalít, v ktorých sa pôvodné umenie spoločensky aj hodnotou postupne emancipovalo práve pričinením sa Vaššom tematizovaných generácií tvorivých osobností. Martin Vašš sa tak v čase a za spoluúčasti výrazných osobností postupne presúval od jednej publikácie do tej nasledujúcej rozšírením časového a personálneho záberu tak, aby nazeranie na umenie a na jeho tvorcov prekročilo územie a historické danosti prvej spoločnej republiky po prvej svetovej vojne, ale aj po druhej svetovej vojne smerom do inšpirujúcej a mýtom jedinečnosti a výnimočnosti obalenej európskej metropoly umenia, do Paríža.

Na vyrozprávanie toho a o tých, čím ho zaujali v študovaných materiáloch si zvolil Martin Vašš v publikácii (naisto nie v monografii) Zmenení Parížom, slovenskí umelci a Paríž v 2o. storočí spoločenské a personálne reálie odvíjajúce sa najčastejšie od tretieho desat'ročia v minulom storočí až po v živote finálne a personálne náčrty, ktoré mu poskytli dostupné fondy o tvorivých činovníkoch dobovej slovenskej a českej kultúry (štúdiá a osobnosti výtvarného prostredia dobovej Prahy).

Čitatel' docení iniciačnú ambíciu autora a publikácie Zmenení Parížom, vyvolat' hlbší a odborne precízne profilovaný záujem poznat prínosy prítomnosti slovenských a českých umelcov v Praží od tridsiatych rokov až do povojnovej prítomnosti, teda 
pokročit' za autorovo úsilie ponúknut' nateraz torzo, a tak do celku dotvárat’ ním načrtnuté situácie jednotlivcov o tom, ako všetko so všetkým v spoločnosti súvisí, ako sa ret’azí náhoda so schválnostou, či ako sa latentne prevaluje minulost' do prítomnosti, no nielen v umení a kultúre.

Historik Martin Vašš pripravil pre širokú čitatel'skú obec pripomenutými publikáciami, v ktorých sa svojou odbornost’ou vyrovnáva s genézou a presadzovaním sa slovenskej kultúry a jej tvorcov v spoločenskej realite minulého storočia až po ušlachtilý vzdelávací zámer autora ponúknut’ čitatelom publikácie pre každého a pre všetkých. Vlastne pre toho, kto nie je odborne vo vzt’ahu ku kultúre, užšie voči umeniu vyprofilovaný, ale prirodzene vníma pohyby tak v umení, ako aj v kultúre.

Hodnoty Vaššových publikácií s tematikou umenia a jeho tvorcov sa spájajú aktuálnostou a dostupnost’ou s tým, o čom ich autor píše a on sám, predpokladáme, najskôr očakáva, že týmto podnetom navodí medzi viacerými čitatelmi záujem o to, akým spôsobom možno vykročit po jeho stope dalej a hladat' o tom či inom umelcovi, o tej či inej udalosti tie súvislosti aj okolnosti, ktoré presvedčia o prirodzenom prepojení a o vývinových väzbách medzi históriou, dejinami a reálnym spoločenským aj osobným životom tých osobností, ktoré Martin Vašš vo svojich publikáciách spojil s tým, čo poskytovala dobová kultúra a dobová kultúrna prax vo svojej členitosti a jedinečnosti známym aj pozabudnutým tvorcom v nie tak dávnej slovenskej a českej spoločenskej minulost'. Pozornost' si zaslúži M. Vaššov zámer obnovit’ poznanie o využitých, uskutočnených aj pozabudnutých príležitostiach, ktoré vnášali do slovenskej a českej národnej kultúry vo vývine neprehliadnutelné vzdelávacie, profesijné a osobné kontakty.

Naračným prístupom $\mathrm{k}$ osobnému aj odbornému materiálu autor obnovuje okolnosti, ktoré tvorivo menili a nie raz aj zmenili ním oživené príhody zo života jednotlivých umelcov, ich svojský literárny a výtvarný svet, ale i to, ako tvorcovia umenia reagovali na premeny, ktoré žilo a zažilo európske umenie od tridsiatych rokov po koniec minulého storočia po dotykoch s mestom a umeleckou povestou Paríža, ale i bez neho. Dobové premeny slovenskej a československej kultúry, reálneho spoločenského a umeleckého sveta spájali umelcov nielen s Bratislavou, Prahou, Berlínom, Budapeštou, ale predovšetkým s mýtickým Parížom až po udalosti štyridsiatych rokoch, ktoré ho o svetovú prestiž velkomesta snov, slávy, jedinečných osobností, urbanistickej krásy, tvorivého experimentu a volnosti postupne pripravovali.

Martin Vašš oživovaním osobných aj odborných, spomienkových a výkladových zdrojov, ktoré si osvojil z informácií a dokumentov naznačuje, ako sa v rýchlom svete a v náročnom živote spontánne kráti a vytráca spoločná pamät na tých, čo tu boli, na to, čím pôsobili vo svojom tvorivom prostredí osobito a čo zanechali v dejinách aj pre 
prítomnost’ súčasnej kultúre, umeniu, výtvarnému umeniu, architektúre, umeleckej a odbornej literatúre.

Meno $\mathrm{k}$ menu, pomenovanie $\mathrm{k}$ pomenovaniu, názov $\mathrm{k}$ názvu, príhoda $\mathrm{k}$ príhode, lahký nadhlad ponad život tvorivej osobnosti a jej prítomnost’ v dejinách umenia, svojho odboru a v kultúrnej pamäti spoločnosti, tým ponúka Martin Vašš užitočné a potrebné oslovenia, ba možno pre čujných čitatelov aj výzvu nezanechat' informácie z jeho publikácíi ležat' ladom a spresňovat' dalším štúdiom, skladaním mozaiky celok a hodnotu jednotlivca.

Okolností, ktorými možno pokračovat’ v jeho rozprávaní po dočítaní publikácie Zmenení Parížom si Martin Vašš uvedomuje a upozorňuje, „Musím ale hned podotknút, že som nemal v úmysle vypracovat' dielo encyklopedického charakteru, ale spracovat' dostatočne reprezentatívny výber osobností, na základe ktorého je možné postačujúcim spôsobom pochopit' tento viacdimenzionálny fenomén a identifikovat' jeho hlavné vývojové etapy". ${ }^{1}$ Toto autorovo vymedzenie sa voči téme a žánru publikácie má svoj význam, zvlášt' vtedy, keby dali o sebe vediet’ odborné zneistenia, či takto a o tomto sa účinne dá vytvorit' (ilustračná) kultúrna mapa slovenských umelcov z ich študijných pobytov, málokedy zo štúdií v Paríži v 20. storočí. Podnet pre záujemcov na širšie a hlbšie dotvárania súvislostí z pôsobenia jednotlivcov zahrnutých do publikácie $\mathrm{v}$ slovenskom umení napomôžu do vydania publikácie zaradené poznámky a vysvetlenia detailu, na ktorý sa autor v texte odvoláva. Čitatelia s uznaním ocenia prospešný odkaz autora na odbornú literatúru a na dalšie zdroje, s ktorými na vzniku publikácie pracoval.

Viera Žemberová

\section{Literatúra:}

VAŠŠ, M.: Zmenení Parížom, slovenskí umelci a Paríž v 2o. storočí. Bratislava: Marenčin PT 2020, 243 s. ISBN 978-80-569-0443-5.

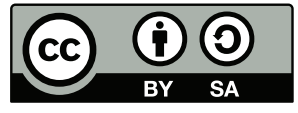

This work can be used in accordance with the Creative Commons BY-SA 4.0 International license terms and conditions (<https://creativecommons.org/licenses/by-sa/4.0/legalcode>). This does not apply to works or elements (such as images or photographs) that are used in the work under a contractual license or exception or limitation to relevant rights.

1 VAŠŠ, M.: Zmenení Parížom, slovenskí umelci a Paríž v 2o. storočí. Bratislava: Marenčin PT 2020 , s. 6. 